\title{
Polymerization of Isobutyl Vinyl Ether by Diethylaluminum Chloride. Requirement of Cocatalyst ${ }^{1}$
}

\author{
Hirotaka Hirata, * Takeo Araki, and Hisaya TANi** \\ Department of Polymer Science, Faculty of Science, Osaka University, \\ Toyonaka, Osaka, 560, Japan.
}

(Received April 25, 1972)

\begin{abstract}
In the polymerization of isobutyl vinyl ether, $\mathrm{Et}_{2} \mathrm{AlCl}$ was inactive by itself and highly activated by oxygen. A limited amount of oxygen contacted with $\mathrm{Et}_{2} \mathrm{AlCl}$ at $-78^{\circ} \mathrm{C}$ gave a stereoregular polymer in a good yield. The catalytically active species was stable only at low temperatures. Iodometrical titration and low temperature IR spectroscopy indicated that the concentration of the active species was proportional to that of the peroxide, e.g., $\mathrm{EtAl}(\mathrm{OOEt}) \mathrm{Cl}$, a thermally unstable intermediate formed in the course of oxidation of $\mathrm{Et}_{2} \mathrm{AlCl}$ by oxygen. $\mathrm{EtAl}\left(\mathrm{OOCMe}_{2} \mathrm{Ph}\right) \mathrm{Cl}$ catalyses the process in a similar fashion to that of the "low temperature $\mathrm{Et}_{2} \mathrm{AlCl}-\mathrm{O}_{2}$ catalyst system." The oxidation of $\mathrm{Et}_{2} \mathrm{AlCl}$ and the catalytic activity of the products are studied. The effects of carbon dioxide are reasonably interpreted in terms of the competitive coordination between oxygen and carbon dioxide toward organo-aluminums.

KEY WORDS Isobutyl Vinyl Ether / Cationic Polymerization / Stereospecific Polymerization / Diethylaluminum Chloride / Lewis Acid / Carbon Dioxide / Ethylchloroaluminum Ethoxide / Aluminum Peroxide / Catalyst /
\end{abstract}

Diethylaluminum chloride has been known as one of the Lewis acids whose chemical structure is definite. ${ }^{1}$ In 1959, Natta, et al., ${ }^{2}$ discovered that the polymerization of vinyl ethers using this compound as catalyst gave a stereoregular polymer. Later on, the catalyst was applied to the stereospecific polymerization of $\alpha$ - or $\beta$ substituted vinyl ethers. ${ }^{3}$ Since in vinyl ethers delocalization of the electrons from the alkoxide group toward the olefinic double bond remarkably facilitated catonic polymerization, it appeared natural that the monomer might be activated by the weakly acidic Lewis acid diethylaluminum chloride.

Recently, Razuvaev ${ }^{4}$ revealed that the electric conductivity of diethylaluminum chloride was only $1 / 25$ of ethylaluminum dichloride. The very low conductivity of the former was later confirmed in the authors' laboratory. ${ }^{5}$ No indication of the existence of ionic species in

* Present address: Faculty of Pharmacy, Nagoya City University, Tanabe-dori, Mizuho, Nagoya, Japan. This report is from his $\mathrm{PhD}$ Thesis, Osaka University, 1969.

** To whom inquiry should be sent.
$\mathrm{Et}_{2} \mathrm{AlCl}$ was obtained by spectroscopic studies by Hoffmann, ${ }^{6}$ Yamamoto, ${ }^{1}$ and Mach. ${ }^{7}$ With the ether complex, occurrence of the intramolecular redistribution reaction was ruled out. ${ }^{8}$ All of these results point out a substantial difference in ionic properties between diethylaluminum chloride and ethylaluminum dichloride.

These facts encouraged the authors to study the active species in the $\mathrm{Et}_{2} \mathrm{AlCl}$ catalyst with a view to attaining an effective polymerization with a high stereospecificity and to producing a true picture of the catalyst behavior.

More recently, Kennedy ${ }^{9}$ showed that the initiating cationic species were formed by adding alkyl halides in the case of $\mathrm{Et}_{2} \mathrm{AlCl}$-catalyzed polymerization of isobutene, which is also one of the monomers favoring cationic polymerization.

It has been disclosed by the authors that $\mathrm{Et}_{2} \mathrm{AlCl}$ is utterly inactive for the polymerization of isobutyl vinyl ether (IBVE) and requires some atmospheric substances as cocatalyst: ${ }^{10}$ Water stimulated $\mathrm{Et}_{2} \mathrm{AtCl}$ to be an active catalyst for polymerization without stereospecificity and oxygen for a highly stereospecific polymerization. The stereospecificity with $\mathrm{Et}_{2} \mathrm{AlCl}$ activated by 
a small amount of oxygen surpassed the values ever obtained with any other homogeneous catalyst system hitherto known.

In this paper, the experimental findings on the catalytic behavior of $\mathrm{Et}_{2} \mathrm{AlCl}$ in the presence or absence of oxygen are described, and the active species of $\mathrm{Et}_{2} \mathrm{AlCl}-\mathrm{O}_{2}$ catalyst system is discussed. A characteristic effect due to carbon dioxide on the catalyst system is also involved.

\section{EXPERIMENTAL}

\section{Materials}

Toluene. Commercial reagent was purified by usual method. It was then dried over metallic sodium and fractionally redistilled under a nitrogen atmosphere just before use.

IBVE. Commercial reagent (Mitsubishi Chemical Co. Ltd.) was refluxed repeatedly under a nitrogen atmosphere over fresh metallic sodium, and then fractionally distilled under a nitrogen atmosphere, bp $82.9^{\circ} \mathrm{C}$. Purity determined by GLC was $99.2 \%$.

$\mathrm{Et}_{2} \mathrm{AlCl}$. Commercial reagent (Ethyl Corp.) was refluxed in the presence of sodium chloride (purity, 99.99\%) in order to remove contaminated $\mathrm{EtAlCl}_{2}$, and then fractionally distilled under reduced pressure, bp $69.4^{\circ} \mathrm{C}(3.0 \mathrm{~mm})$. Purity of $\mathrm{Et}_{2} \mathrm{AlCl}-96.7 \%$ for commercial, and 99.5\% for purified-was determined by DTA analysis ${ }^{11}$ by assuming the heat of fusion for a pure sample was $1.0 \pm 0.3 \mathrm{kcal} / \mathrm{mol}$.

$E t A l(O E t) C l$. This compond was prepared by equimolar reaction of $\mathrm{Et}_{2} \mathrm{AlCl}$ with absolute ethanol in benzene under a nitrogen atmosphere, and then fractionally distilled under reduced pressure, bp $35^{\circ} \mathrm{C}\left(10^{-3} \mathrm{~mm}\right)$. Analyses for active ethyl groups by gasometry and for aluminum content were consistent with calculated values. The molecular weight determined cryoscopically corresponded to the trimer. ${ }^{12}$

$(\mathrm{EtO})_{2} \mathrm{AlCl}$. This compound was prepared by reacting two moles of absolute ethanol with one mole of $\mathrm{Et}_{2} \mathrm{AlCl}$, and used after distilling off the solvent.

Cumene Hydroperoxide. The commercial reagent was used without further purification.

EtAl(OCOEt $) \mathrm{Cl}$. This compound was prepared by equimolar reaction of $\mathrm{Et}_{2} \mathrm{AlCl}$ with propionic acid in benzene under a nitrogen atmosphere, and purified by distillation under reduced pressure, bp $129^{\circ} \mathrm{C}(0.1 \mathrm{~mm})$. The analyses of active ethyl group and of aluminum content were consistent with the calculated values.

Oxygen. Oxygen which had been dried by passing through a column $(120 \mathrm{~cm}$ in length and $3.0 \mathrm{~cm}$ in diameter) packed with phosphorus pentoxide was bubbled through a glass pipette into the catalyst solution at the rate of $100 \mathrm{ml} /$ min except for at ambient temperature $(50 \mathrm{ml} /$ min). Addition of oxygen in high vacuum was carried out by bubbling dry oxygen from a reservoir attached to the polymerization flask containing a toluene solution of $\mathrm{Et}_{2} \mathrm{AlCl}$ through a capillary tube.

Carbon dioxide. Carbon dioxide generated by thermal decomposition of purified sodium carbonate was dehydrated by passing through columns of calcium chloride and of phosphorus pentoxide, successively.

\section{Polymerization}

By either of the following procedures IBVE was polymerized for $24 \mathrm{hr}$ in a polymerization flask immersed in a Dry Ice-methanol bath.

Procedure A. Method under a Nitrogen Atmosphere. The polymerization flask was filled with dried nitrogen after evacuating to $c a \cdot 10^{-1}$ $\mathrm{mm}$. Solvent (toluene, $15 \mathrm{ml}$ ), catalyst solution ( $0.02 \mathrm{~mol}$ of catalyst per mole of IBVE) and IBVE was successivly added to the flask with hypodermic syringes.

Procedure B. High Vacuum Method. Monomer and solvent were refluxed over metallic sodium under a nitrogen atmosphere and then distilled under $10^{-5}-\mathrm{mm}$ pressure through a breakable seal into a small vessel coated with a sodium mirror. This distillation was usually repeated three or four times. The vessels containing the last distillates and oxygen were connected to the polymerization flask separated by breakable seals, which was thoroughly baked and degassed for a long time under $10^{-5}-\mathrm{mm}$ pressure. Solvent was first introduced into the flask and then catalyst (in a small ampoule which was crushed in the polymerization flask) followed by oxygen (contained in a small vessel with a breakable seal). After the mixture had been stirred magnetically at the given temperature, chilled 
monomer was added at $-78^{\circ} \mathrm{C}$ with stirring, and the flask was kept at $-78^{\circ} \mathrm{C}$ for the polymerization.

\section{Detection of Peroxide}

Peroxydic material was detected by the usual method. ${ }^{13}$ In a well baked polymerization flask

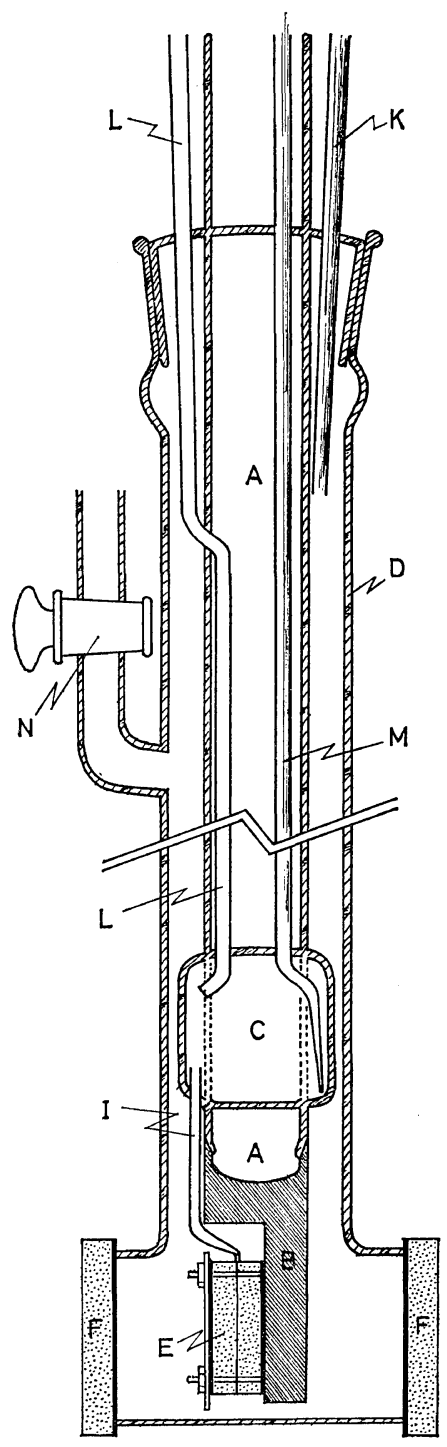

Figure 1. Diagram of the apparatus for IR mearurement at low temperature: $\mathrm{A}$, reservoir for a cold liquid; $\mathrm{B}, \mathrm{KBr}$ cell holder (copper block); C, reactor; D, jacket; $\mathrm{E}$, sample cell $(\mathrm{KBr}) ; \mathrm{F}$, window $(\mathrm{KBr})$; I, sample transfer tube; $\mathrm{K}$, inert gas inlet tube; L, sample inlet tube; $\mathbf{M}$, reaction gas bubbling tube; $\mathrm{N}$, tap for evacuation. flushed with dry nitrogen, a solution of $1.53 \times$ $10^{-4} \mathrm{~mol}$ of $\mathrm{Et}_{2} \mathrm{AlCl}$ in $15 \mathrm{ml}$ of toluene was placed. After a definite amount of oxygen had been bubbled in at $-78^{\circ} \mathrm{C}$ or $0^{\circ} \mathrm{C}$, a slightly acidified 5-\% ethanolic potassium iodide solution was added. Liberated iodine was titrated with standardized sodium thiosulfate solution.

\section{IR Measurement at Low Temperature}

By the use of specially designed apparatus (Figure 1) allowing $\mathrm{Et}_{2} \mathrm{AlCl}$ to contact with oxygen at a chosen condition, the change in absorption bands during the autoxidation at low temperature was successfully observed. The apparatus is constructed of double glass cylinders. The inner cylinder involves a reservoir (A) for the cooling material, a reactor (or a sample holder) (C) and a cell holder (made of copper block) (B) joined to the reservoir (A). The outer cylinder (D) having the $\mathrm{KBr}$ windows (F) is equipped with several narrow tubes for supplying dry inert gas $(\mathrm{K})$ and for introducing oxygen (M). The space between the two cylinders was filled with inert gas in order to avoid evaporation of the solvent. The $\mathrm{KBr}$ windows were maintained fully transparent to the IR beam during the measurement, even at the very low temperature, by blowing dry nitrogen gas toward them.

\section{Stereospecificity of the Polymerization Reaction}

Methanol-insoluble crude polymer $(0.5 \mathrm{~g})$ was fractionated by keeping it in $100 \mathrm{~m} l$ of methyl ethyl ketone (MEK) at $30^{\circ} \mathrm{C}$ for $48 \mathrm{hr}$. The index of stereospecificity of the polymerization reaction (IS) was calculated as follows: IS= (MEK-insol polymer (g)) $\times 100 /($ Methanol-insol polymer (g)).

\section{Polymer}

The solution viscosity $\left(\eta_{\mathrm{sp}} / c\right)$ of crude polymer in benzene at $30^{\circ} \mathrm{C}(1 \mathrm{~g} / 100 \mathrm{ml})$ ranged from 2.2 to 4.6. The MEK-insoluble fraction of the polymer showed absorption bands at 1340 and $980 \mathrm{~cm}^{-1}$ indicating isotactic polymer (mp max $\left.110^{\circ} \mathrm{C}\right)$.

\section{RESULTS}

\section{Catalytic Behavior of $\mathrm{Et}_{2} \mathrm{AlCl}$}

As long as commercial $\mathrm{Et}_{2} \mathrm{AlCl}$ was used without particular attention to its purity, the 
reproducibility of the polymerization results for IBVE was very poor, i.e., polymer yield, $61.4 \pm 36 \%$; isotactic polymer yield, $28.3 \pm 28.3 \%$; IS, $29 \pm 29 \%$, for eight runs. By using purified $\mathrm{Et}_{2} \mathrm{AlCl}(99.5-\%$ purity) as catalyst and by excluding oxygen and water as completely as possible from the polymerization system, the yield of polymer reduced markedly with an improved reproducibility, i.e., polymer yield, $3.7 \pm 3.4 \%$, for nine runs. The catalytic activity of the purified $\mathrm{Et}_{2} \mathrm{AlCl}$ was almost independent of catalyst concentration $(0.01-0.15 \mathrm{~mol} / \mathrm{mol}$ monomer), excluding the possibility that some materials contained in the solvent and/or monomer might deactivate the catalytic effect of $\mathrm{Et}_{2} \mathrm{AlCl}$.

The fact that under a high vacuum the polymerization mixture produced no detectable amount of polymer nor oligomer (by GLC) after two weeks at $-78^{\circ} \mathrm{C}$, confirms that $\mathrm{Et}_{2} \mathrm{AlCl}$ is catalytically inactive and that IBVE itself cannot activate $\mathrm{Et}_{2} \mathrm{AlCl}$ as a cocatalyst under that condition.

\section{Effect of Oxygen}

Amount. Under a high vacuum, $\mathrm{Et}_{2} \mathrm{AlCl}$ was made remarkably active by contacting it with excess amount of oxygen, producing isotactic polymer (Table I). The dependence of the activity of $\mathrm{Et}_{2} \mathrm{AlCl}-\mathrm{O}_{2}$ system on the amount of oxygen bubbled at $-78^{\circ} \mathrm{C}$ under nitrogen is illustrated in Figure 2. As the bubbling time increased, sharp activation $(20-40 \mathrm{sec})$ followed by deactivation $(1 \mathrm{~min})$ was observed. The IS-

Table I. Polymerization by $\mathrm{Et}_{2} \mathrm{AlCl}-\mathrm{O}_{2}$ system under high vacuum condition ${ }^{\mathrm{a}}$

\begin{tabular}{|c|c|c|c|c|}
\hline \multirow{2}{*}{$\begin{array}{c}\mathrm{Et}_{2} \mathrm{AlCl} \\
\mathrm{mol}\end{array}$} & \multirow{2}{*}{$\begin{array}{l}\mathrm{O}_{2} \\
\mathrm{~m} l\end{array}$} & \multirow[b]{2}{*}{$\mathrm{O}_{2} / \mathrm{Al}^{\mathrm{b}}$} & \multicolumn{2}{|c|}{ Polymer } \\
\hline & & & $\underset{\%}{\text { Yield, }}$ & $\begin{array}{l}\text { IS, } \\
\%\end{array}$ \\
\hline $6.9 \times 10^{-4}$ & 5.5 & 0.4 & trace & - \\
\hline $3.3 \times 10^{-4}$ & 10 & 1.3 & 100 & 12 \\
\hline $6.9 \times 10^{-4}$ & 23 & 1.5 & 100 & 60 \\
\hline
\end{tabular}

a Polymerization: IBVE, $1 \times 10^{-2} \mathrm{~mol}$; toluene, $15 \mathrm{ml}$; temp, $-78^{\circ} \mathrm{C}$; polymerization time, $24 \mathrm{hr}$; $\mathrm{O}_{2}$ bubbling, $-78^{\circ} \mathrm{C}$.

b This value denotes the ratio of "total" moles of oxygen introduced into the system to moles of $\mathrm{Et}_{2} \mathrm{AlCl}$. The amount of "absorbed" oxygen into the organo-aluminum was not determined.

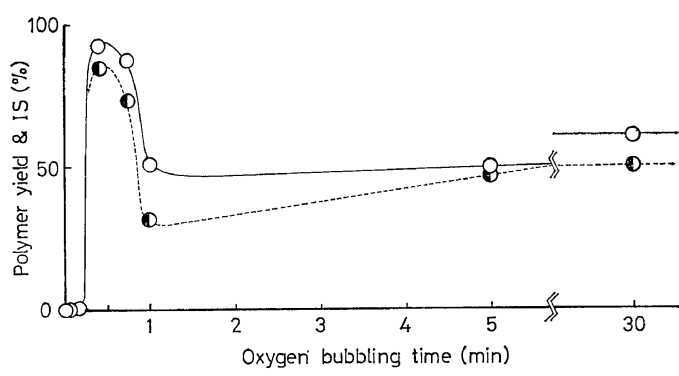

Figure 2. Polymerization catalysed by $\mathrm{Et}_{2} \mathrm{AlCl}-$ $\mathrm{O}_{2}$ system: $\bigcirc$, yield; $\mathrm{D}, \mathrm{IS} ; \mathrm{Et}_{2} \mathrm{AlCl}, 1.53 \times 10^{-4}$ mol; toluene, $15 \mathrm{ml}$; IBVE, $7.63 \times 10^{-3} \mathrm{~mol}$; Polymerization temp, $-78^{\circ} \mathrm{C}$; time, $24 \mathrm{hr}$. Oxygen bubbling was carried out at $-78^{\circ} \mathrm{C}$ at the flow rate of $100 \mathrm{ml} / \mathrm{min}$.

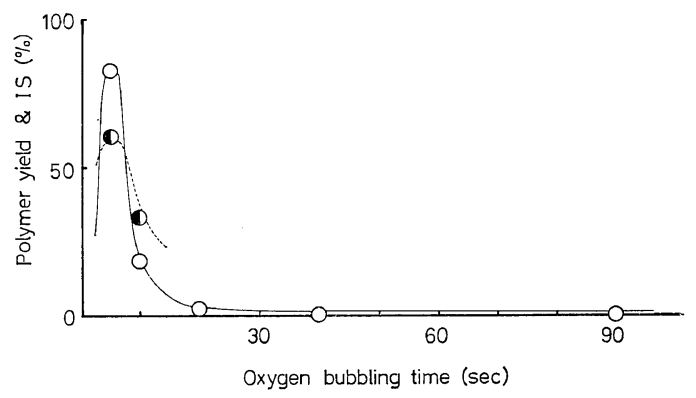

Figure 3. Polymerization catalysed by $\mathrm{Et}_{2} \mathrm{AlCl}-$ $\mathrm{O}_{2}$ system: $\bigcirc$, yield; $\mathrm{O}$, IS. Oxygen was bubbled at room temperature at the flow rate of $50 \mathrm{ml} / \mathrm{min}$.

value curve gave similar results showing nearly $90 \%$ in the optimum region and $50-60 \%$ for prolonged bubbling. ${ }^{*}$ Bubbling at room temperature resulted in steep activation at extremely short bubbling times $(5-10 \mathrm{sec})$ followed by sharp deactivation as shown in Figure 3.

Temperature. Figure 4 illustrates the temperature dependence of the activity of the $\mathrm{Et}_{2} \mathrm{AlCl}-$ $\mathrm{O}_{2}$ system under a nitrogen atmosphere. The $\mathrm{Et}_{2} \mathrm{AlCl}-\mathrm{O}_{2}$ system kept for about $30 \mathrm{~min}$ at $-78^{\circ} \mathrm{C}$ showed a slight change in activity and IS value. Sharp depression of the activity was. observed at $0^{\circ} \mathrm{C}$ over a short period $(30-60 \mathrm{sec})$. The results obtained by bubbling oxygen at specified temperature (Figure 5) indicate that the active species giving stereoregular polymer is stable only at low temperatures and is con-

* The highly stereospecific $\mathrm{Et}_{2} \mathrm{AlCl}-\mathrm{O}_{2}$ catalyst system is referred to hereafter as "low temperature $\mathrm{Et}_{2} \mathrm{AlCl}-\mathrm{O}_{2}$ catalyst system." 


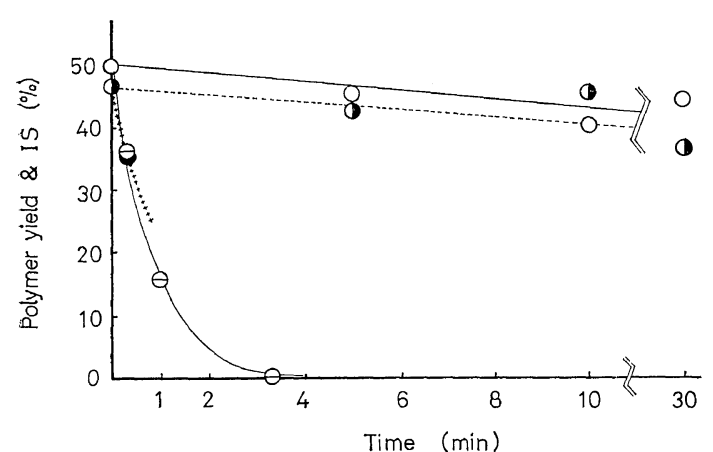

Figure 4. Dependence of the catalytic activity on the aging time: $\bigcirc$, yield, aged at $-78^{\circ} \mathrm{C} ;$ IS, aged at $-78^{\circ} \mathrm{C}$; $\ominus$, yield, aged at $0^{\circ} \mathrm{C}$; $\odot$, IS, aged at $0^{\circ} \mathrm{C}$.

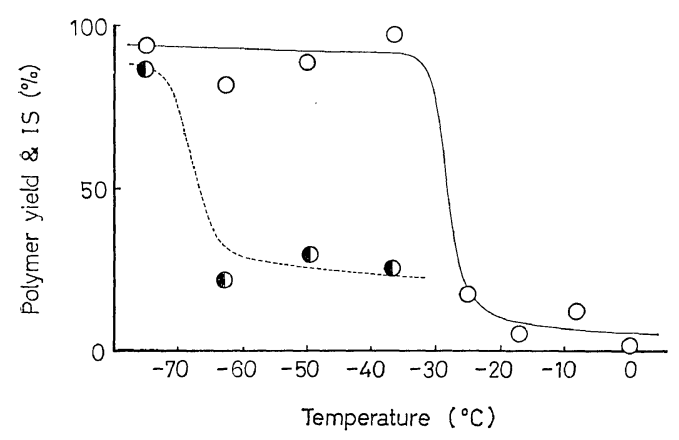

Figure 5. Catalytic activity of $\mathrm{Et}_{2} \mathrm{AlCl}-\mathrm{O}_{2}$ system in terms of aging temperature: $\bigcirc$, polymer yield; D, IS. Abscissa shows the temperature preserved for ten minutes after oxygen bubbling at $-78^{\circ} \mathrm{C}$.

verted into nonstereoregular species soon after the temperature was raised. The activity was retained at a high value up to about $-30^{\circ} \mathrm{C}$.

\section{Iodometric Titration of $\mathrm{Et}_{2} \mathrm{AlCl}-\mathrm{O}_{2}$ System}

The presence of peroxidic substance in the $\mathrm{Et}_{2} \mathrm{AlCl}-\mathrm{O}_{2}$ system was examined by iodometric titration under the same oxygen bubbling condition as that used in the polymerization experiment. The experimental results (Figure 6) revealed that the amount of peroxide formed in this reaction depended on the extent of oxygen bubbling and on the temperature at which oxygen was bubbled. The inflection point of the sigmoidal curve due to the formation of peroxide did correspond to the point at which sharp activation by oxygen was observed in the $\mathrm{Et}_{2} \mathrm{AlCl}-\mathrm{O}_{2}$ system (see Figure 2).

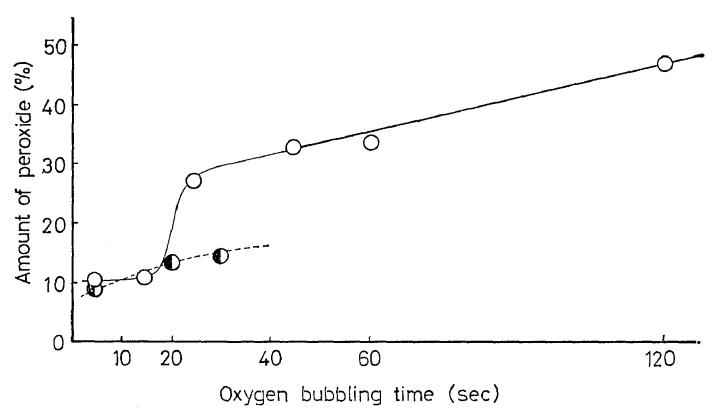

Figure 6. Formation of peroxide by bubbling oxygen into $\mathrm{Et}_{2} \mathrm{AlCl}$ toluene solution: $\mathrm{O}$, at $-78^{\circ} \mathrm{C} ; \quad C$, at $0^{\circ} \mathrm{C}$; $\mathrm{Et}_{2} \mathrm{AlCl}, 1.53 \times 10^{-4} \mathrm{~mol}$; toluene, $15 \mathrm{ml}$. The amount of peroxide was measured by iodometry and calculated as $\mathrm{Al}(\mathrm{OOEt}) \mathrm{EtCl}$.

\section{IR Spectroscopy of Organo-aluminums}

IR examination at low temperature supports the hypothesis of the existence of an intermediately formed substance as being a peroxide of $\mathrm{Et}_{2} \mathrm{AlCl}$ (Figure 7). Very rapid changes in the IR spectrum of $\mathrm{Et}_{2} \mathrm{AlCl}$ were observed soon after contacting $\mathrm{Et}_{2} \mathrm{AlCl}$ with oxygen at $-78^{\circ} \mathrm{C}$; a characteristic new absorption band appearing at $1013 \mathrm{~cm}^{-1}$ was apparently different from that of $\mathrm{Et}_{2} \mathrm{AlCl}$ and of its stable oxidation product $\mathrm{EtAl}(\mathrm{OEt}) \mathrm{Cl}$.

Catalytic Behavior of Some Derivatives of $\mathrm{Et}_{2} \mathrm{AlCl}$ Et $\mathrm{Al}\left(\mathrm{OOCM} \mathrm{O}_{2} \mathrm{Ph}\right) \mathrm{Cl}$. This compound was prepared from $\mathrm{Et}_{2} \mathrm{AlCl}$ with cumene hydroperoxide (CHP) as a model compound of the peroxide EtAl(OOEt)Cl, the stereospecifically active species suggested in the autoxidation of $\mathrm{Et}_{2} \mathrm{AlCl}$ with oxygen. The model peroxide system formed at $-78^{\circ} \mathrm{C}$ by mixing CHP with $\mathrm{Et}_{2} \mathrm{AlCl}$ at various molar ratios exhibited stereospecific activity (Figure 8). CHP added even in a very small amount converted the inactive $\mathrm{Et}_{2} \mathrm{AlCl}$ to a highly active species. The catalytic activity of the model peroxide system showed an analogous dependence to that of the $\mathrm{Et}_{2} \mathrm{AlCl}-\mathrm{O}_{2}$ system, that is, mixing only at a low temperature resulted in high yield of polymers with relatively high IS value and the activity was sharply depressed at a mixing temperature around $-60^{\circ} \mathrm{C}$ where the active species of $\mathrm{Et}_{2} \mathrm{AlCl}-\mathrm{O}_{2}$ system was assumed to be converted into an inactive species (Figure 9). The some- 


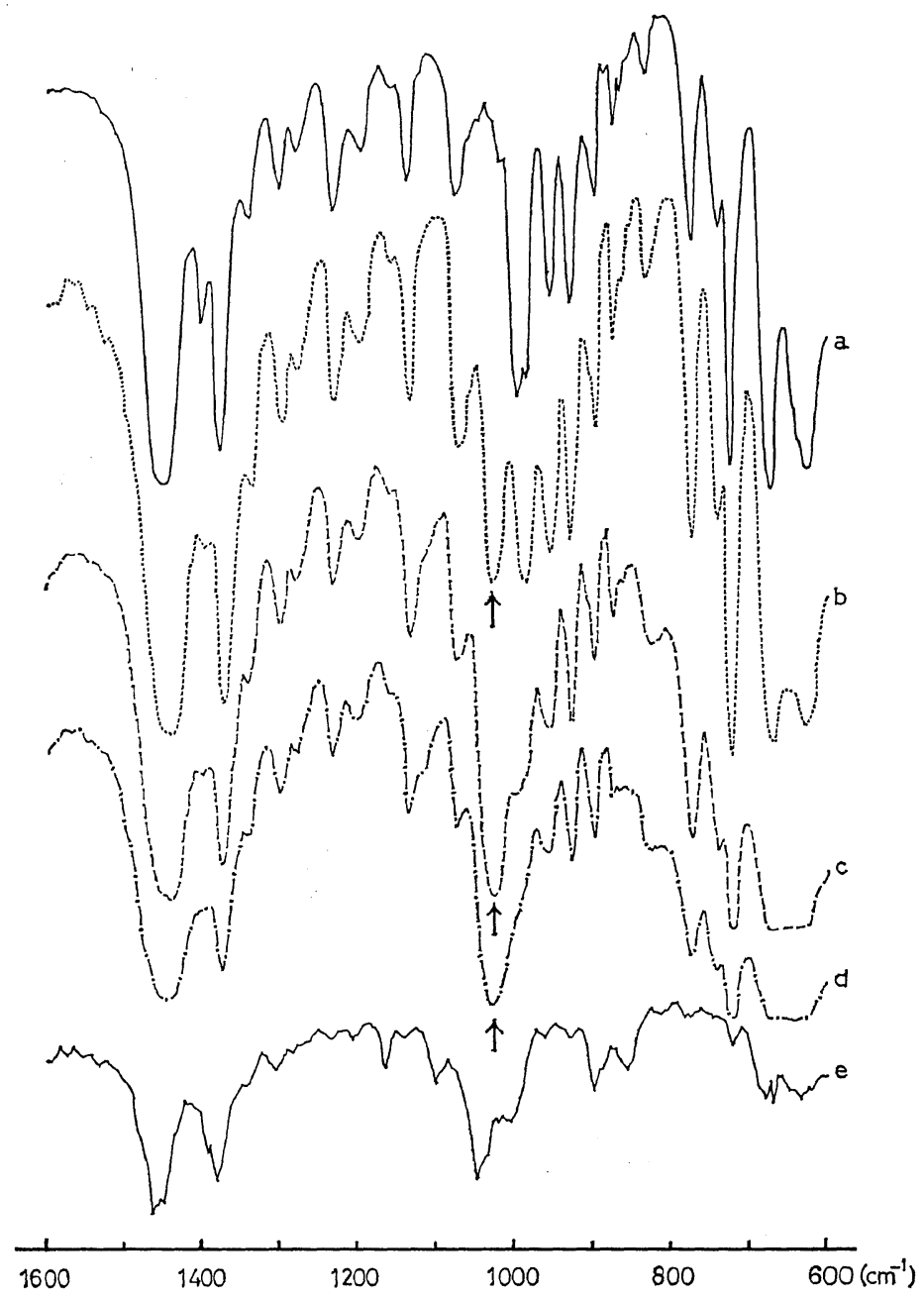

Figure 7. Changes in IR absorption spectra of $\mathrm{Et}_{2} \mathrm{AlCl}-\mathrm{O}_{2}$ system: a, $\mathrm{Et}_{2} \mathrm{AlCl}$ (pure); b, very soon after; c, $12 \mathrm{~min}$ after; d, $25 \mathrm{~min}$ after contact with oxygen; e, $\operatorname{EtAl}(\mathrm{OEt}) \mathrm{Cl}$. Arrows show the newly appeared band $\left(1013 \mathrm{~cm}^{-1}\right)$ due to contact with oxygen. The band is absent in both $\mathrm{Et}_{2} \mathrm{AlCl}$ and $\mathrm{EtAl}(\mathrm{OEt}) \mathrm{Cl}$.

what lower IS value observed in the EtAl$\left(\mathrm{OOCMe}_{2} \mathrm{Ph}\right) \mathrm{Cl}$ system than in the $\mathrm{Et}_{2} \mathrm{AlCl}-\mathrm{O}_{2}$ system would represent the lesser suitability of the calalyst structure for stereoregulation; e.g., weakly associated bridged-structure of the former catalyst.

$(\mathrm{EtO})_{2} \mathrm{AlCl}$. The fact that this compound was inactive (Table II) provides a reasonable interpretation for the experimental observation that $\mathrm{Et}_{2} \mathrm{AlCl}$, once activated by oxygen at an ambient temperature, soon becomes inactive again (see Figure 3), because $\mathrm{Et}_{2} \mathrm{AlCl}$ would be ultimately oxidized to $(\mathrm{EtO})_{2} \mathrm{AlCl}$ at a high rate at the temperature range in question.

EtAl(OEt)Cl. EtAl $(\mathrm{OEt}) \mathrm{Cl}$ was active in itself (Table II) exhibiting a lower activity and poorer stereoregulating function than did the $\mathrm{Et}_{2} \mathrm{AlCl}-$ $\mathrm{O}_{2}$ catalyst system. In addition, the existence of some interaction between $\mathrm{Et}_{2} \mathrm{AlCl}$ and $\mathrm{EtAl}(\mathrm{OEt}) \mathrm{Cl}$ depresses the catalyst activity of the latter (Figure 10). 


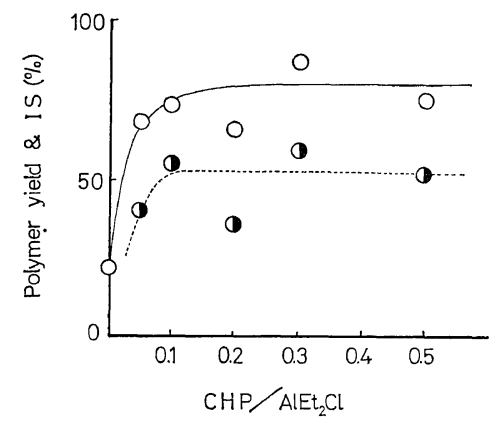

Figure 8. Polymerization catalysed by $\mathrm{Et}_{2} \mathrm{AlCl}-$ CHP system; $\bigcirc$, yield; 1 , IS; $\mathrm{Et}_{2} \mathrm{AlCl}, 1.53 \times 10^{-4}$ mol; toluene, $15 \mathrm{ml}$; IBVE, $7.63 \times 10^{-3} \mathrm{~mol}$; polymerization temp, $-78^{\circ} \mathrm{C}$; time, $24 \mathrm{hr}$; mixing of $\mathrm{Et}_{2} \mathrm{AlCl}$ with $\mathrm{CHP},-78^{\circ} \mathrm{C}$.

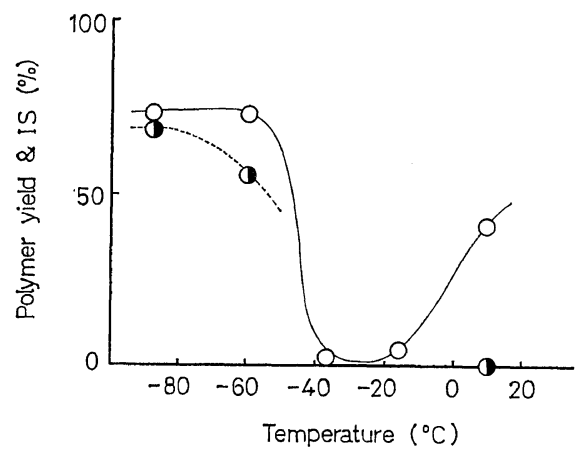

Figure 9. Dependence of polymerization catalysed by $\mathrm{Et}_{2} \mathrm{AlCl}-\mathrm{CHP}$ system mixed at different temperatures: $O$, polymer yield; $O$, IS; CHP/ $\mathrm{Et}_{2} \mathrm{AlCl}, 0.7$.

\section{Effect of Carbon Dioxide}

The addition of carbon dioxide to $\mathrm{Et}_{2} \mathrm{AlCl}$ under various conditions had virtually no cocatalytic effect (Figure 11). In this respect,

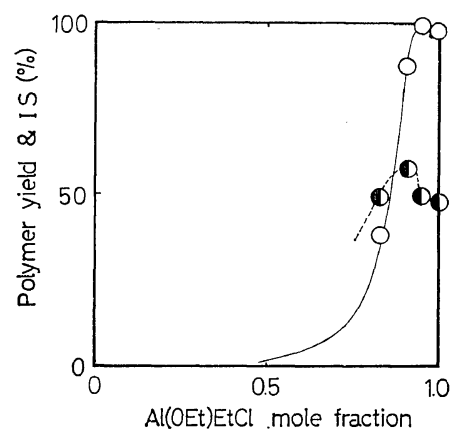

Figure 10. The catalytic behaviour of $\mathrm{Et}_{2} \mathrm{AlCl}-$ $\operatorname{EtAl}(\mathrm{OEt}) \mathrm{Cl}$ system: $\bigcirc$, polymer yield; $\boldsymbol{O}$, IS; $\operatorname{EtAl}(\mathrm{OEt}) \mathrm{Cl}, 1.53 \times 10^{-4} \mathrm{~mol}$; toluene, $15 \mathrm{ml}$; IBVE, $7.63 \times 10^{-3} \mathrm{~mol}$; polymerization temp, $-78^{\circ} \mathrm{C}$; time, $24 \mathrm{hr}$.

carbon dioxide is sharply contrasted to oxygen. This result seems quite natural in view of the known fact that carbon dioxide cannot be inserted in the $\mathrm{Al}$ - Et bond of $\mathrm{Et}_{2} \mathrm{AlCl}^{15}$ However, the catalytic behavior of the $\mathrm{Et}_{2} \mathrm{AlCl}-\mathrm{O}_{2}$ system varies significantly in the presence of carbon dioxide. The activation of the $\mathrm{Et}_{2} \mathrm{AlCl}$ with oxygen was apparently inhibited or retarded by pretreating it with carbon dioxide (Figure 11). Another interesting effect of carbon dioxide is the stabilization of the activity in the $\mathrm{Et}_{2} \mathrm{AlCl}-$ $\mathrm{O}_{2}$ catalyst system by pretreating $\mathrm{Et}_{2} \mathrm{AlCl}$ with a small amount of carbon dioxide (Figure 12).

EtAl $(\mathrm{OCOEt}) \mathrm{Cl}$ prepared by the equimolar reaction between $\mathrm{Et}_{2} \mathrm{AlCl}$ and propionic acid showed a fairly high stereospecific activity for the polymerization of IBVE independent of the bubbling of oxygen (Figure 13). This result provides new information that a series of such

Table II. Polymerization catalysed by ethoxides ${ }^{a}$

\begin{tabular}{|c|c|c|c|c|c|}
\hline Catalyst & $\begin{array}{l}\text { Concn, } \\
\text { mol } \% / \text { monomer }\end{array}$ & IBVE, mol & Yield, \% & IS, $\%$ & Exptl technique \\
\hline $\mathrm{Al}(\mathrm{OEt})_{2} \mathrm{Cl}$ & 2.0 & $7.63 \times 10^{-3}$ & 0.0 & - & $\mathrm{N}_{2}$ atmospheric \\
\hline $\mathrm{EtAl}(\mathrm{OEt}) \mathrm{Cl}$ & 0.5 & " & 6.6 & - & " \\
\hline$" 1$ & 1.0 & $"$ & 17.3 & 32 & $"$ \\
\hline " & 2.0 & " & 35.3 & 59 & $"$ \\
\hline " & 5.0 & " & 94.9 & 43 & " \\
\hline " & 10.0 & " & 64.4 & 51 & " \\
\hline$"$ & 4.8 & $11.46 \times 10^{-3}$ & $65.5^{\mathrm{b}}$ & - & High vacuum \\
\hline
\end{tabular}

a Polymerization in $15 \mathrm{ml}$ toluene, at $-78^{\circ} \mathrm{C}$ for $24 \mathrm{hr}$.

b Polymerization period, $48 \mathrm{hr}$. 


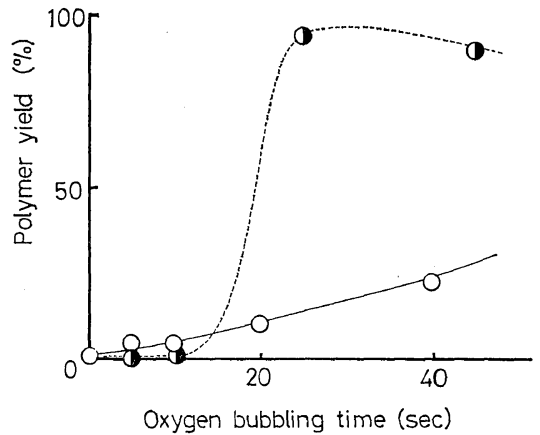

Figure 11. Effect of $\mathrm{CO}_{2}$ added to $\mathrm{Et}_{2} \mathrm{AlCl}-\mathrm{O}_{2}$ catalyst system: $\bigcirc, \mathrm{CO}_{2}$ bubbling for $60 \mathrm{sec}$ $(100 \mathrm{ml} / \mathrm{min})$ at room temperature prior to oxygen bubbling; without $\mathrm{CO}_{2} ; \mathrm{Et}_{2} \mathrm{AlCl}, 1.53 \times 10^{-4}$ $\mathrm{mol}$; toluene, $15 \mathrm{ml}$; IBVE, $7.63 \times 10^{-3} \mathrm{~mol}$; polymerization temp, $-78^{\circ} \mathrm{C}$; time, $24 \mathrm{hr}$. Oxygen bubbling was carried out at $-78^{\circ} \mathrm{C}$ at a flow rate of $100 \mathrm{ml} / \mathrm{min}$.

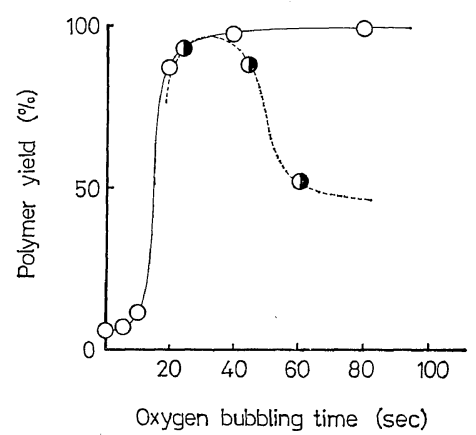

Figure 12. Activity change of $\mathrm{Et}_{2} \mathrm{AlCl}-\mathrm{O}_{2}$ system in the presence or absence of $\mathrm{CO}_{2}: \mathrm{O}, \mathrm{CO}_{2}$ bubbling for $3 \mathrm{sec}\left(100 \mathrm{ml} / \mathrm{min}, \mathrm{CO}_{2} / \mathrm{Et}_{2} \mathrm{AlCl}=1.4\right)$ at room temperature prior to oxygen bubbling; C. no $\mathrm{CO}_{2}$. Oxygen and $\mathrm{CO}_{2}$ bubblings were carried out at a fiow rate of $100 \mathrm{ml} / \mathrm{min}$.

types of compound can be stereospecifically active in the apparently homogeneous system.

\section{DISCUSSION}

These results revealed that the catalytic activity of $\mathrm{Et}_{2} \mathrm{AlCl}$ in the stereospecific polymerization of IBVE is not as simple as has been suggested but is rather more complex. Although the full scheme of the reaction between catalyst activity and active-inactive entities cannot be drawn, a brief feature of the relation is now

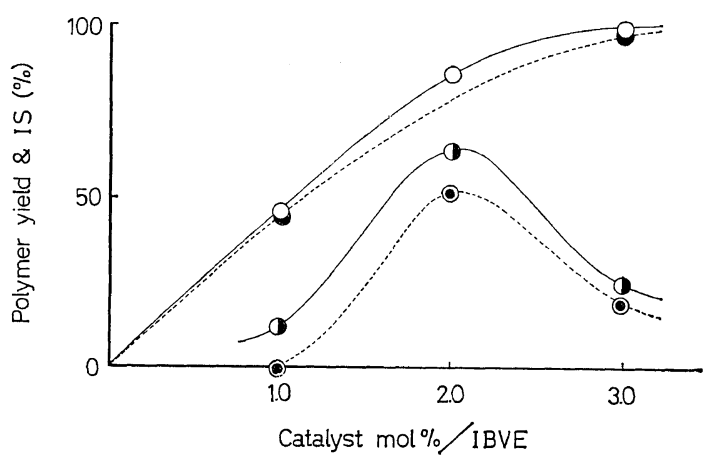

Figure 13. Polymerization catalysed by Et. $\mathrm{Al}(\mathrm{OCOEt}) \mathrm{Cl}$ with or without oxygen system: $\bigcirc$, yield, without oxygen; IS, without oxygen; - yield, with oxygen bubbling for $30 \mathrm{sec}$; $\odot$, IS, with oxygen bubbling for $30 \mathrm{sec}$; toluene, 15 $\mathrm{ml}$; IBVE, $7.63 \times 10^{-3} \mathrm{~mol}$; polymerization temp, $-78^{\circ} \mathrm{C}$; time, $24 \mathrm{hr}$.

disclosed: $\mathrm{Et}_{2} \mathrm{AlCl}$ alone-inactive; $\mathrm{Et}_{2} \mathrm{AlCl}+$ $\mathrm{H}_{2} \mathrm{O}$ (at $-78^{\circ} \mathrm{C}$, very small amount)-highly active without stereoregulation; $\mathrm{Et}_{2} \mathrm{AlCl}+\mathrm{O}_{2}$ (under particular condition)-active with stereoregulation; $\mathrm{EtAl}(\mathrm{OEt}) \mathrm{Cl}$-fairly active with some stereoregulation; $(\mathrm{EtO})_{2} \mathrm{AlCl}$-inactive; $\mathrm{Et}_{2} \mathrm{AlCl}+$ $\mathrm{CO}_{2}$-inactive.

Referred to the stereoregular active entity, oxygen was found to make a significant contribution. To interpret the catalytic behaviors of the $\mathrm{Et}_{2} \mathrm{AlCl}-\mathrm{O}_{2}$ system, the oxidation processes of $\mathrm{Et}_{2} \mathrm{AlCl}$ must be considered. For the autoxidation of organometallic compounds, it has been reported ${ }^{14}$ that various kinds of materials are formed depending on the character of the metal-carbon bond. In general, autoxidation of the metal-alkyl compounds proceeds through the following scheme to the ultimate formation of the alcoholate. ${ }^{15}$

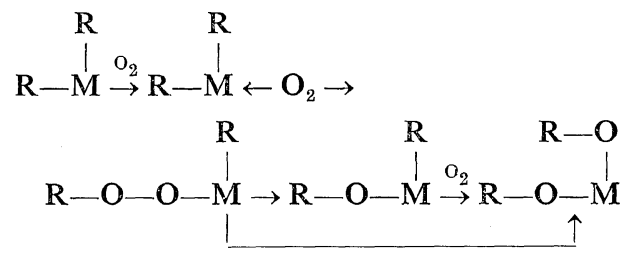

The oxygen complex is well known to date in the case of transition metals, ${ }^{16}$ but not clearly identified for aluminum or boron. ${ }^{17,18}$ Peroxide, ROOM, was identified for lithium and magne- 
sium at very low temperatures, and for the more electropositive metals, e.g., zinc and cadmium, the peroxides are more stable and can be handled safely ${ }^{14}$ even at $0^{\circ} \mathrm{C}$. Knowledge of the autoxidation of organo-aluminum compounds is still lacking, but such reaction intermediates, especially of peroxide, are also likely for alkyl-borons ${ }^{19}$ and -aluminum compounds. ${ }^{20}$

The most important finding of this study is that the correlation of stereoregular activity with the existence of a peroxidic substance in the catalyst system is fairly satisfactory, indicating that the concentration of the active species is proportional to that of the peroxide which is stable only at low temperatures. Further oxidation proceeds with increases in the amount of oxygen or elevation of the contact temperature to give $\mathrm{EtAl}(\mathrm{OEt}) \mathrm{Cl}$ and $(\mathrm{EtO})_{2} \mathrm{AlCl}$, successively. The catalytic behavior of $\mathrm{Et}_{2} \mathrm{AlCl}-$ $\mathrm{O}_{2}$ varies almost correspondingly to the formation of such oxidation products.

Some additional factors affecting the catalytic behavior of the $\mathrm{Et}_{2} \mathrm{AlCl}-\mathrm{O}_{2}$ system are found to be due to the existence of carbon dioxide, unreacted $\mathrm{Et}_{2} \mathrm{AlCl}$ or IBVE. For example, $\mathrm{Et}_{2} \mathrm{AlCl}$ depresses the activity of $\mathrm{EtAl}(\mathrm{OEt}) \mathrm{Cl}$ probably as a result of mutual interaction, and carbon dioxide stabilizes $\mathrm{Et}_{2} \mathrm{AlCl}$ and $\mathrm{Et}_{2} \mathrm{AlCl}$ $\mathrm{O}_{2}{ }^{*}$ The monomer exhibits a similar stabilization effect to that of the carbon dioxide but to a lesser extent. ${ }^{* *}$ A series of experiments along the same lines showed that strongly Lewis-basic compounds such as quinoline completely inhibited the activation process by oxygen.

The stabilizing effects of carbon dioxide can be interpreted as the result of the competitive coordination toward $\mathrm{Et}_{2} \mathrm{AlCl}$ by the oxygen molecule, and of the inhibition of the intramolecular rearrangement of active species in $\mathrm{Et}_{2} \mathrm{AlCl}-\mathrm{O}_{2}$ into less active -oxides by the coordinated carbon dioxide. The $\mathrm{Et}_{2} \mathrm{AlCl}-\mathrm{O}_{2}$ system can be compared with the $n-\mathrm{BuMgBr}-\mathrm{O}_{2}$ catalyst system reported by Bruce and Farren, ${ }^{21}$

* The action of carbon dioxide also produced behavior similar to that due to oxygen in the activation of commercial grade $\mathrm{Et}_{2} \mathrm{AlCl}$.

** When oxygen was bubbled in the presence of the monomer, the amount required for obtaining effective catalyst activity was much higher than that in the absence of the monomer. though the stereospecificity of the latter catalytic system is not unambiguous. The difference in the catalytic activities between $n-\mathrm{BuMgBr}-\mathrm{CO}_{2}$ and $\mathrm{Et}_{2} \mathrm{AlCl}-\mathrm{CO}_{2}$ system was remarkable. The higher cocatalytic activity of carbon dioxide in the Grignard reagent was shown to exist by the same authors, whereas the cocatalytic activity of carbon dioxide in the case of $\mathrm{Et}_{2} \mathrm{AlCl}$ was not observed. This difference is presumably due to the difference in the reactivity of carbon dioxide toward these organo-metallics as shown below

$$
\begin{aligned}
& \mathrm{Et}_{2} \mathrm{AlCl}+\mathrm{CO}_{2} \longrightarrow \mathrm{Et}_{2} \stackrel{\mathrm{CO}_{2}}{\downarrow} \\
& \mathrm{BuMgBr}+\mathrm{CO}_{2} \longrightarrow \mathrm{BuMgBr} \longrightarrow \mathrm{BuCO}_{2} \mathrm{MgBr}
\end{aligned}
$$

The fact that the reaction product obtained from $\mathrm{Et}_{2} \mathrm{AlCl}$ and propionic acid was a highly active catalyst suggests that at least one of the constituents involving $\mathrm{EtCO}_{2} \mathrm{AlEtCl}$ is catalytically active. The active catalyst species in $\mathrm{BuMgBr}-\mathrm{CO}_{2}$ system can also be related with $\mathrm{BuCO}_{2} \mathrm{MgBr}$ in a specific manner. ${ }^{21}$ On this basis, it must be a general feature of structures involving metal carbonates in the catalyst that they are effective catalytically for IBVE polymerization.

A wide variety of studies made until now have indicated that IBVE is one of the monomers polymerizable solely by a cationic mechanism. When the propagation reaction proceeds by an anionic mechanism, a condition in which the lone-pair electrons on the ether oxygen atom do not migrate toward the $\pi$-electrons on the carbon-carbon double bond must be realized. Such a condition may be possible if the coordination of the lone-pair electrons with a metal in a catalyst is well established during the propagation reaction, and alternatively if conjugation of the lone-pair electrons with vinylic $\pi$-electrons are inhibited by some steric requirement in the $\mathrm{C}=\mathrm{C}-\mathrm{O}$ bond. For the free-radical initiation analogous requirements are necessary. These specific states related to electronic or steric requirement is unlikely in the systems reported in this paper. Therefore, at the present stage, it seems safe to assume that 
the cationic mechanism is predominant in the polymerization of IBVE by $\mathrm{Et}_{2} \mathrm{AlCl}-\mathrm{O}_{2}$ catalyst systems.

The reason why the peroxidic state is so effective for stereospecific polymerization of the monomer is not clear at the present stage. It should be noted that the $\mathrm{M}-\mathrm{O}-\mathrm{O}$ bond in the peroxide group is highly cleavable in a lowenergy process. For example a very small amount of water, ${ }^{*}$ if present, is enough to assist the polarization of the bond. The resultant weakly protonic acid will contribute to the initiation of the polymerization and the counter anion may subsidiarily participate in the stereoregulation.<smiles>[R]OO[Al]([R])Cl</smiles>

As has been indicated, isotactic propagation of this monomer occurs rather easily in a homogeneous condition without any special requirement for the structure of the counter anion. ${ }^{22}$ Judged from the melting point $\left(110^{\circ} \mathrm{C}\right)$ and IR spectrum of this polymer, the tacticity does not greatly exceed** that of isotactic polymers obtained by the usual stereospecific homogeneous catalysts. This fact suggests that the stereoregulating ability of the counter anion (above) itself is not a predominant factor as in other catalyst systems.

On the other hand, a decrease in the amount of atactic polymer in the authors' case indicates

* Even using the experimental techniques of this paper, absolutely dry systems cannot be guaranteed. Water can therefore be a prime candidate for the initiating reagent. The next candidate is $\mathrm{R}+$ derived from the reaction $\mathrm{RClAlO}^{+} \rightarrow \mathrm{R}^{+}+\mathrm{ClAl}=\mathrm{O}$, but it is difficult to explain the stereoregulating function. Heterolytic fission at $\mathrm{Al}-\mathrm{O}$ bond of peroxide yielding $\mathrm{Al}^{+}$and $\mathrm{ROO}^{-}$seems less probable in view of the bond strength, rather than $\mathrm{H}^{-}$abstraction from the monomer.

** With the heterogeneous catalyst, Vandenberg 23 obtained a polymer with very high isotacticity. that a weak Lewis acid containing an oxygen atom with high polarizability will be an effective stereospecific catalyst requiring an extremely small amount of cocatalyst. A larger amount of the cocatalyst frequently causes side reactions disturbing the sterically regular propagation. Stronger Lewis acids such as $\mathrm{Et}_{2} \mathrm{AlCl}$ or $\mathrm{EtAlCl}_{2}$ tend to give atactic polymers when water is added as a cocatalyst. As $\mathrm{EtAlCl}_{2}$ is a very strong Lewis acid, it requires ${ }^{24}$ a much smaller amount of water to yield an atactic polymer at a high rate. A weak Lewis acid with low polarizability ordinally requires a larger amount of cocatalyst.

Acknowledgement. The authors wish to thank Professr S. Seki of Department of Chemistry, Osaka University, for the discussion on DTA analysis, Professor H. Mikawa and Dr. N. Kusabayashi of Department of Applied Chemistry, Osaka University, for helpful discussions on instrumentation of the low-temperature IRcell device. They are grateful to Mitsubishi Chemical Co., Ltd. for providing the isobutyl vinyl ether.

\section{REFERENCES}

1. O. Yamamoto, Bull. Chem. Soc. Japan, 35, 619 (1962).

2. G. Natta, G. Dall'Asta, G. Mazzanti, U. Giannini, and S. Cesca, Angew. Chem., 71, 205 (1959).

3. G. Natta, M. Peraldo, M. Farina, and G. Bressan, Makromol. Chem., 55, 139 (1962); K. Matsuzaki, M. Hamada, and K. Arita, J. Polym. Sci., Part A-1, 5, 1233 (1967).

4. G. A. Razuvajev and A. J. Grajevskii, Dokl. Akad. Nauk SSSR, 128, 309 (1959).

5. N. Ueyama, T. Araki, and H. Tani, unpublished result.

6. E. G. Hoffmann, Z. Elektrochem., 64, 616 (1960).

7. K. Mach, Coll. Czech. Chem. Commun., 28, $2295^{\circ}$ (1963).

8. R. Tarao and S. Takeda, Bull. Chem. Soc. Japan, 40, 650 (1967).

9. J. P. Kennedy, Polymer Preprint, 7, 485 (1966).

10. H. Hirata and H. Tani, Polymer, 9, 59 (1968).

11. W. P. White, J. Phys. Chem., 24, 393 (1920).

12. H. Scherer and G. Seydel, Angew. Chem., 75, 846 (1963). 
13. A. G. Davies, "Organic Peroxides," Butterworths Scientific Publns., London, 1961.

14. H. Hock, H. Kropf, and F. Ernst, Angew. Chem., 71, 541 (1959).

15. K. Ziegler, "Organoaluminum Compounds," ACS Monograph, No. 147, Zeiss Ed., Reinhold, New York, N. Y., 1960.

16. S. Takahashi, K. Sonogashira, and N. Hagihara, Nippon Kagaku Zasshi (J. Chem. Soc. Japan, Pure Chem. Sect.), 87, 610 (1966); L. Vaska, Science, 140, 809 (1963).

17. N. L. Zutty and F. J. Welch, J. Org. Chem., 25, 861 (1960).

18. A. G. Davies, D. G. Hare, and O. R. Kahn, J. Chem. Soc., 1125 (1963).

19. M. H. Abraham and A. G. Davies, ibid., 429 (1959).

20. A. G. Davies and C. D. Hall, ibid., 1192 (1963).
21. J. M. Bruce and D. W. Farren, Polymer, 4, 407 (1963).

22. T. Higashimura, T. Yonezawa, S. Okamura, and K. Fujii, J. Polym. Sci., 39, 487 (1959); S. Okamura, T. Higashimura, and $\mathbf{H}$. Yamamoto, ibid., 33, 510 (1958); S. Okamura, T. Higashimura, and I. Sakurada, ibid., 39, 507 (1959); T. Higashimura, K. Suzuoki, and S. Okamura, Makromol. Chem., 86, 259 (1965); D. J. Cram and K. R. Kopecky, J. Amer. Chem. Soc., 81, 2748 (1959); M. Goodman and Y.L. Fan, ibid., 86, 4922 (1964); C. E. H. Bawn and A. Ledwith, Quart. Revs., 16, 361 (1962).

23. E. J. Vandenberg, R. F. Heck, and D.S. Breslow, J. Polym. Sci., 41, 519 (1959).

24. H. Hirata, Ph. D. Thesis, Osaka University, 1969. 